\title{
Using the Capabilities of the Common Digital Space of Scientific Knowledge for Educational Purposes
}

\author{
Nikolay E. Kalenov, Irina N. Sobolevskaya, Alexander N. Sotnikov \\ Joint SuperComputer Center of the Russian Academy of Sciences - Branch of Federal State Institution "Scientific \\ Research Institute for System Analysis of the Russian Academy of Sciences”, Leninsky Prospect, 32a, Moscow, \\ 119334, Russia
}

\begin{abstract}
The role of the Common Digital Space of Scientific Knowledge (CDSSK) in the development of educational technologies is considered. CDSSK is being implemented by a number of Russian organizations as a digital environment of a new generation for the purpose of providing information for scientific research, education, popularization of science and preservation of scientific heritage. The CDSSK structure provides for the formation and support of special components related to secondary and higher education. One of the elements related to education in the structure of the CDSSK is a scientific virtual exhibition. Such an exhibition can be dedicated both to a specific person and a scientific event in general. Virtual exhibitions combine a variety of resources related to the presented topic (biographies of scientists, related museum and archival materials, copies of films, interactive multimedia resources). The paper presents the basic principles of constructing the CDSSK educational component, provides examples of implemented virtual exhibitions used in the educational process. Virtual exhibitions are implemented on the digital library "Scientific Heritage of Russia" platform.
\end{abstract}

\section{Keywords}

Digital Library, Scientific Heritage of Russia, Educational Resources, Virtual Exhibition, Common Digital Space of Scientific Knowledge, I.V. Michurin, M.M. Gerasimov

\section{Introduction}

One of the Common Digital Space of Scientific Knowledge (CDSSK) application areas [1-4] is to support educational processes in Russian schools and universities. As an integrator of existing information systems, including encyclopedic, museum, library, etc., the CDSSK can serve as a source of multidimensional reliable information required at all education stages - from junior secondary school to postgraduate education.

CDSSK is a collection of thematic subspaces related to various sciences, united by a common ontology and objects universal classes. The objects universal classes include "persons" - information about scientists; publications, unpublished documents and general scientific multimedia objects; scientific organizations and societies; general scientific classification systems; geographic objects.

Each thematic subspace contains the basic laws and postulates of the given scientific direction; scientific facts obtained on their basis; links to persons associated with the discovery or application of scientific results; links to publications that reveal the scientific result essence, digital models demonstrating natural phenomena, illustrating the scientific results obtained and their practical application.

Thus, the CDSSK content can be considered as an information base for the educational technologies implementation, provided it is structured in accordance with the various levels educational requirements.

SSI-2021: Scientific Services \& Internet, September 20-23, 2021, Moscow (online)

EMAIL: nkalenov@jscc.ru (N.E. Kalenov), ins@jscc.ru (I.N. Sobolevskaya), asotnikov@jscc.ru (A.N. Sotnikov)

ORCID: 0000-0001-5269-0988 (N.E. Kalenov), 0000-0002-9461-3750 (I.N. Sobolevskaya), 0000-0002-0137-1255 (A.N. Sotnikov)

(c) (1) 1021 Copyright for this paper by its authors.

Use permitted under Creative Commons License Attribution 4.0
CEUR Workshop Proceedings (CEUR-WS.org) 


\section{The CDSSK structure}

In each science area two classes of knowledge can be distinguished:

1. Theoretical

2. Experimental.

Theoretical knowledge is a set of axioms, research methods and fundamental results obtained through the application of these methods. It should be noted that if the postulates and methods of research are formal, declared and established elements recognized by society, then the basic results of theoretical research are a relative concept, which is determined by expert assessments of the scientific community [1].

Experimental scientific knowledge is a set of practical results obtained through the application of theoretical knowledge, confirmed by practice.

Accordingly, the CDSSK each thematic subspace should have two components - fundamental and experimental.

The fundamental component (let's call it the basis) is information reflecting the fixed, time-tested, scientific knowledge. It has the property of being static, changing very slowly over time.

The dynamic component (superstructure) includes information about the latest achievements in this scientific field. After some time, a part of the superstructure may be included into the basis, and another part would be excluded from the CDSSK.

The basis includes several interrelated levels of knowledge representation.

1. Popular science (designed for a wide range of users who are interested in certain scientific facts);

2. Primary (designed for schoolchildren of general education classes);

3. Basic (targeted at high school and undergraduate students studying in this area).

4. Advanced (intended for undergraduates and postgraduates specializing in this scientific direction).

5. Professional (intended for specialists in a given field of science).

The superstructure is a current information source required for scientific research, which complements the base professional level.

Popular science level is mostly static, includes popular science literature, lectures demonstrating scientific phenomena, museum items, multimedia resources aimed at popularizing science. This level content is rarely replenished with information about relatively recently obtained scientific results, which can be presented in a popular form. Information at this level can be used as an illustration of scientific patterns studied, mainly in primary school.

The primary level is static. It is formed by extracting information from textbooks selected by educational experts; it can be widely represented digitized museum exhibits, multimedia popular resources.

The basic level is quasi-static. It rarely changes - only with the appearance of significant results (discoveries) that are fundamental for a given area of knowledge and is formed on the basis of school textbooks selected by experts in this area of knowledge.

The advanced level is quasi-dynamic. It changes as new scientific results are obtained, reflected, first of all, in scientific monographs that have passed expert selection. The content of this level is formed using existing encyclopedias, reference books, authoritative monographs, time-tested textbooks for higher education. This level includes, along with the extracted metadata, links to sources and digital copies of the most significant monographs.

The professional level of the basis includes deeper, in comparison with the advanced level, static information on a given scientific direction. This information is supplemented by new information, confirmed by expert assessments, coming from the superstructure.

The superstructure reflects new results in a particular scientific field. Its content is formed by extracting knowledge from the current published information that has passed the expert selection. The content of the superstructure changes dynamically both due to new information and due to the exclusion of information from it, the value of which has not been confirmed by time.

For educational purposes, the information contained in the basic is mainly used (levels 2-4). The information contained in the superstructure can be claimed by educational processes at the master's and postgraduate level. 


\section{The CDSSK educational resources}

The CDSSK educational resources include two layers:

- resources for school education;

- resources for university education.

The Primary level and the Basic level (partially) are resources basis for school education in general. The content of these components, aimed at school students, includes general information about science in general and its individual areas in accordance with the content of school curricula. This level contains scientific information at the level of a children's encyclopedia, accompanied by full texts of popular science publications designed for schoolchildren. The satellite resources are:

- video materials;

- digitized popular science films;

- models of museum objects and natural phenomena.

Among the component of development of the CDSSK school component are:

- interactive games;

- quizzes and tests containing educational elements.

Resources for each higher education thematic subspace include:

- detailed information about scientists who have significantly contribute to development of this scientific direction;

- digital copies of museum items and archival materials;

- full texts of fundamental educational and scientific publications selected by experts;

- multimedia modeling certain phenomena and working out research methods and solving routine problem.

\section{Implementation example}

The modern version of the electronic library "Scientific Heritage of Russia (DL SHR) (http://eheritage.ru), the architecture of which is described in detail in [6,7], can serve as a simplified model of the CDSSK.

The main purpose of the formation of DL SHR is to provide information via the Internet about outstanding Russian and foreign scientists who worked on the Russia territory, who significantly contributed to the Russian science, and their activities results. The DL SHR contains:

- detailed biographical data about scientists;

- the main stages their scientific activity;

- heterogeneous archival and museum information;

- scanned photographs;

- audio and video recordings;

- digital copies of their main publications.

At present, the DL SHR reflects a significant part of the scientific heritage of Russia to the period from the birth of Russian science (17th century) to the first quarter of the 20th century.

Working with DL SHR [8], the user can search for scientists by last name, first name, patronymic, year and place of birth, year of death, scientific areas in which the scientist worked, biography fragments (full-text search).

In Fig. 1 presents a request and a fragment of the search result for scientists who lived in Russia in the 18-19 centuries, who were engaged in astronomy. There are 40 such scientists in the DL SHR. Each surname in the resulting list is an active link, upon clicking on which a page with information about the scientist and a list of his publications will open, from each of which you can go to view the full text. 


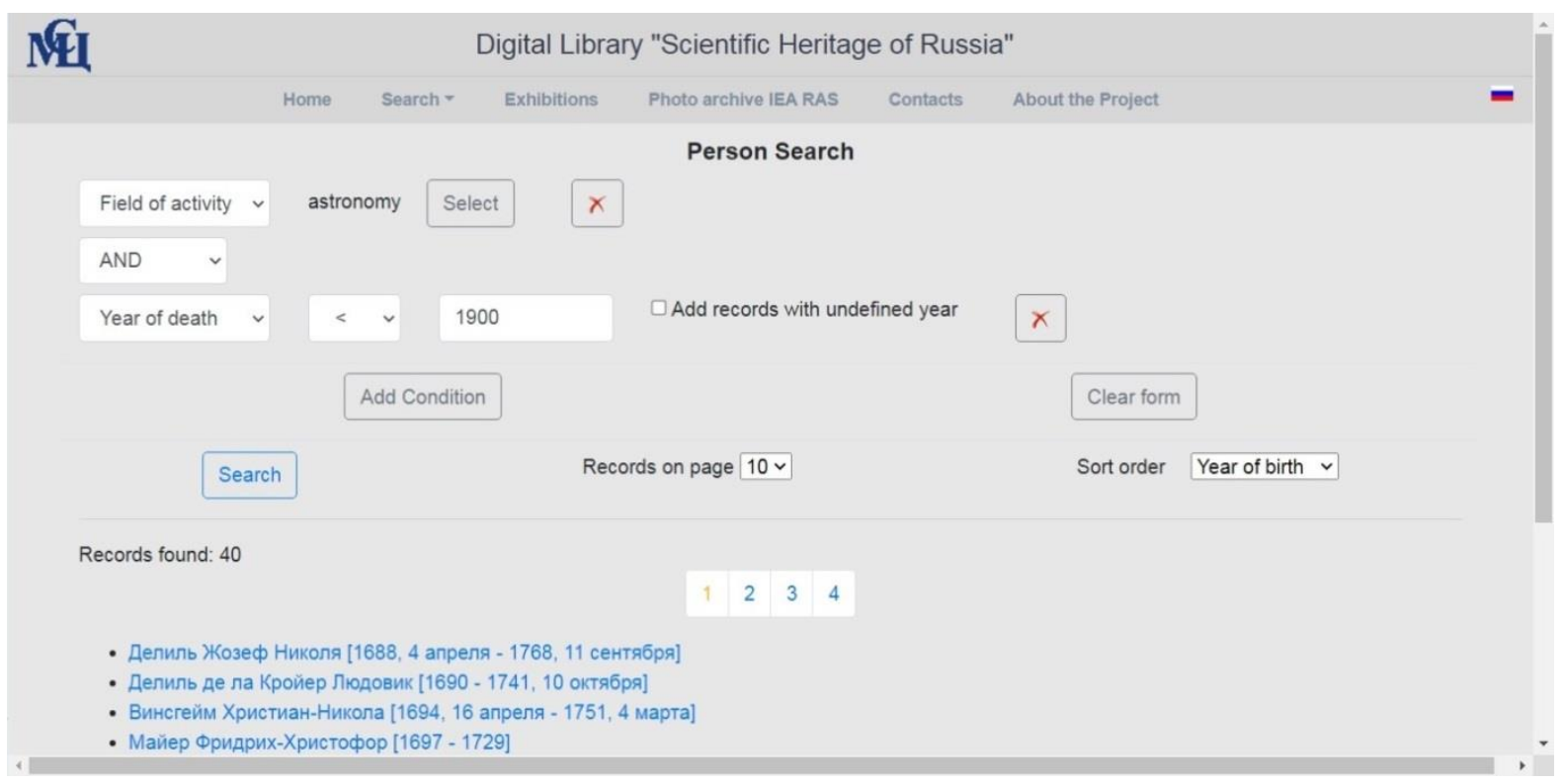

Figure 1: A request and a fragment of the search result for scientists who lived in Russia in the 18-19 centuries, who were engaged in astronomy

In Fig. 2 shows an example of a search for publications in the titles or indexes of which contents the wheel is mentioned. The search results are sorted in ascending order of publication years. There are 31 such publications. When you click on the author's surname, a page opens with a list of all his publications available in the DL NNR. Clicking on the publication title opens a page with bibliographic data of the publication and a link to its full text.

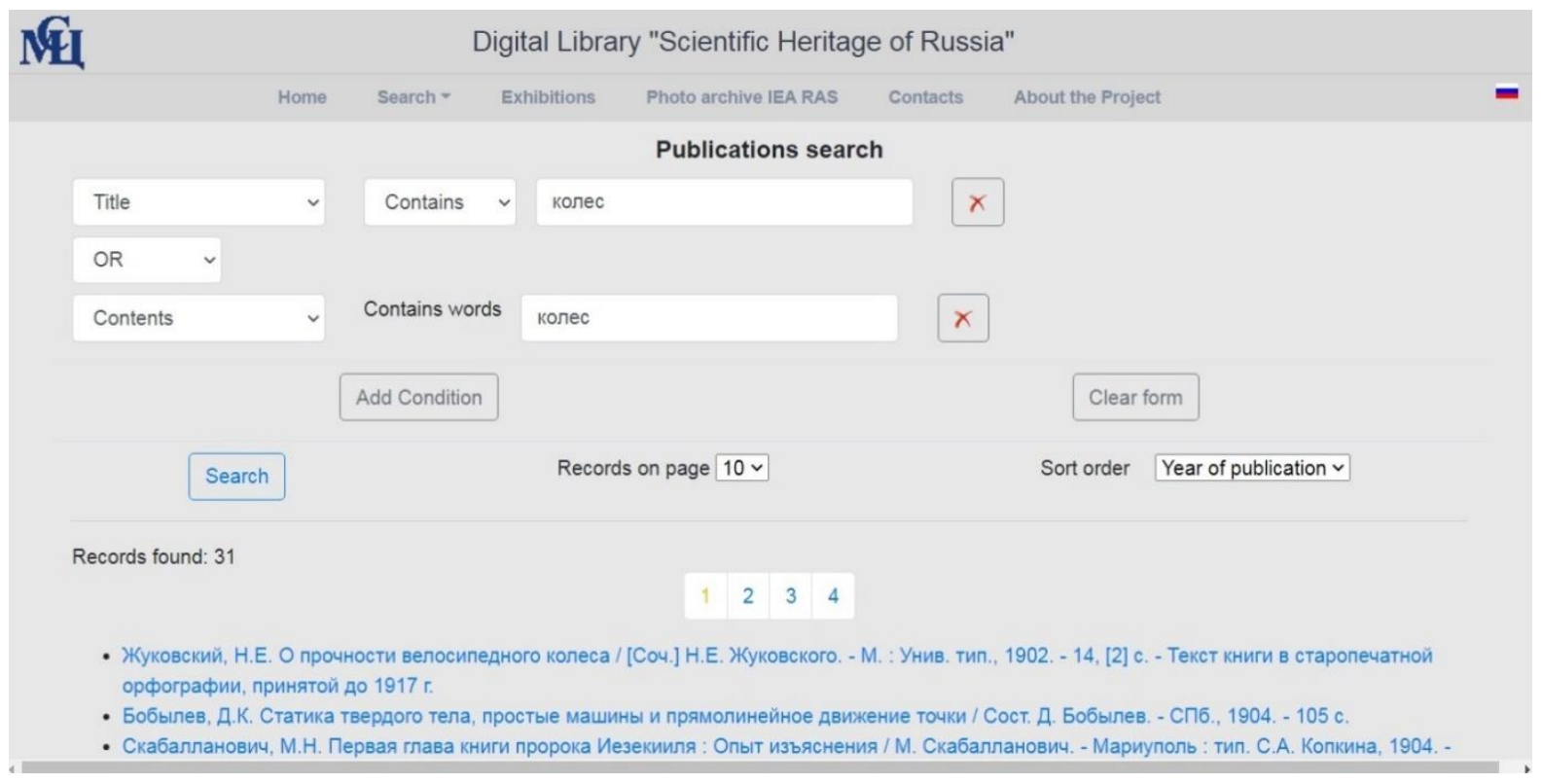

Figure 2: An example of a search for publications in the titles or table of which contents the wheel is mentioned

\section{The virtual exhibition as an example of an educational resource}

One of the ways of using information technologies in educational processes is the virtual exhibitions formation based on the DL SHR resources, providing users with heterogeneous information, united according to certain criteria [9-11]. These can be exhibitions dedicated to an individual scientist, any event, natural phenomenon, etc. 
Despite the fact that each virtual exhibition is unique in its content, the following main sections can be distinguished in the formation of such exhibitions in the CDSSK environment:

- the main thematic section;

- an interactive section;

- biographical section;

- section of video materials;

- section of photographic documents;

- library;

- section "Collection of 3D objects";

- reviews section;

- contacts.

A virtual exhibition can contain general information about a given science area, scientific information both at the level of a children's encyclopedia, and more detailed information. Virtual exhibitions allow you to combine the resources of a thematic subspace, making, among other things, an emphasis on a particular audience.

A practical example of the virtual exhibition use in the school education process is the "Garden of Life" implemented on the DL SHR platform [12], posted in the public domain at http://3d.acadlib.ru.

The Garden of Life exhibition is dedicated to the life and scientific activities of the outstanding Russian biologist and breeder Ivan Vladimirovich Michurin (1855-1935) (Figure 3). The information presented at this exhibition is primarily aimed at schoolchildren [13].
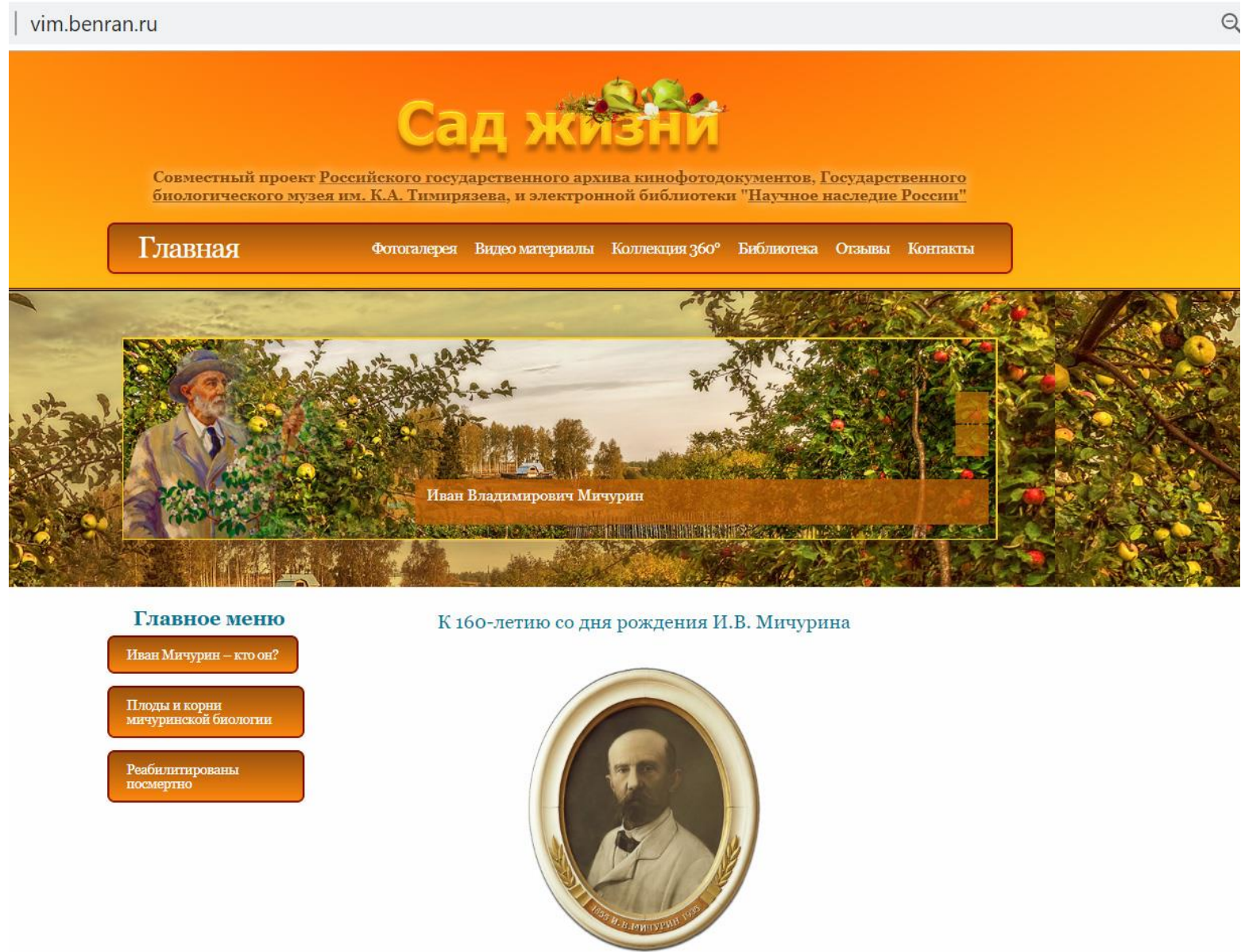

Figure 3: The main page of the "Garden of Life" virtual exhibition

It is thematically divided into two parts: biographical part - "Ivan Michurin - who is he?" (Figure 4) and socio-political part - "The fruits and roots of Michurin biology" (Figure 5). 


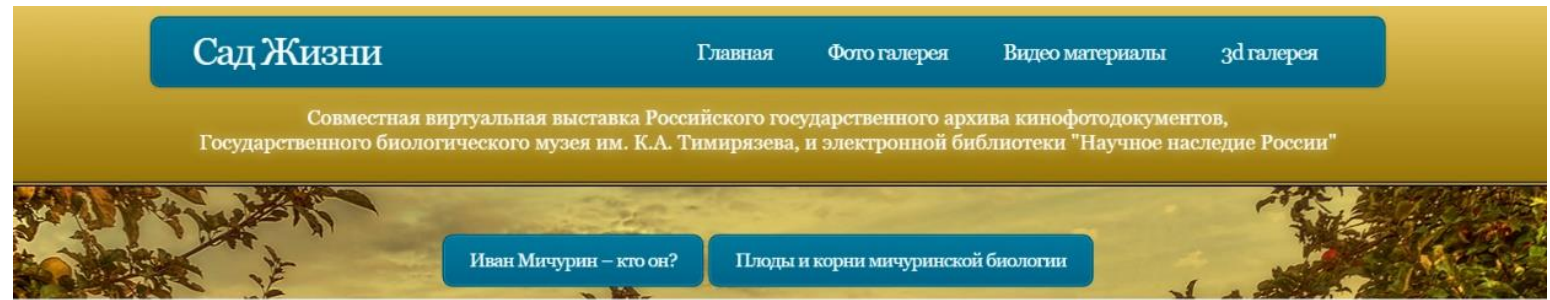

Главное меню

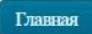

Фото галерея

Видео материалы

3d Галерея
К 16о-летию со дня рождения И.В. Мичурина

$$
\text { Иван Мичурин - кто он? }
$$

Разночинец по происхождению сословию

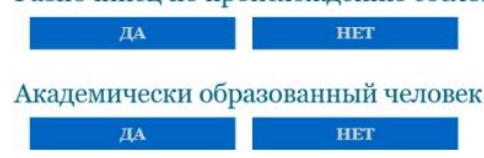

Прирожденный садовод

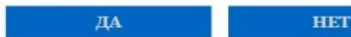

Железнодорожник, механик и электрик

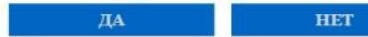

Гражданин города Козлова

Figure 4: biographical part - "Ivan Michurin - who is he?"

Главное меню

Иван Мичурин - кто он?

Плоды икорнів

Реабилитаровань
Плоды и корни мичуринской биологии

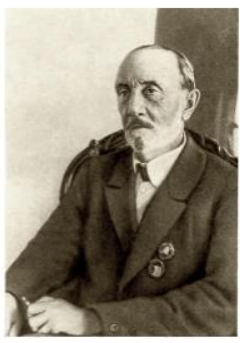

2. ti. Alurepons

Портрет Ивана Владпмировгта Митурина пз книги «Итоги шестидесятнлетних рабоб» (Mockвa, 1950).

И.В. Мичурин никогда не создавал общебиологического учения. Уже после его смерти Т. Д. Лысенко, энергичный, но малообразованный агроном наполнил наследие талантливого селекционера преимущественно собственным содержанием и назвал систему своих взглядов «мичуринской биологией».

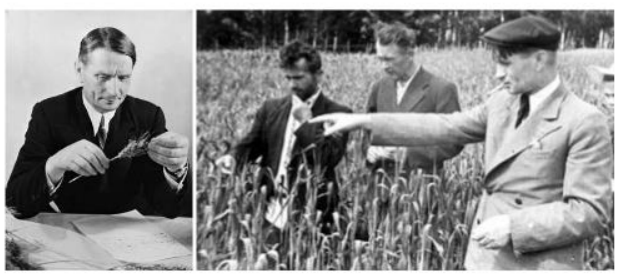

Трофим Денисович Лысенко (1898-1976) - советский агроном, академикАН Украины (1934), АН СССР (1939),академик (1935) и президент (1938-1956 и 1961-1962) ВАСХНИЛ, Герой Социалистического Труда (1945); создатель псевдонаучного «мичуринского учения» в биологии. Отрицал классическую генетику и утверждал возможность

Figure 5: Socio-political part - "The fruits and roots of Michurin biology" 
The biographical section is built in the genre of an interview game interactive. First, the user is given curious facts or well-established judgments about Michurin and is asked to choose the correct statement. Then the user's choice is refuted or confirmed by documents, photographs, or museum items.

The section "The Fruits and Roots of Michurin Biology" refers to the history of science in the part related to conflicts in the second third of the 20th century between groups of Soviet scientists who supported and refuted genetics. It also divided into two parts. Visitors to the exhibition are told what was the essence of the conflict between the warring parties, and explained on the basis of facts that I.V. Michurin had nothing to do with these events.

The virtual exhibition has the following sections:

- Photo gallery. This section contains photographic documents from the funds of the Russian State Archive of Documentary Films and Photographs (RSADFP) and State Biological Museum named after K.A. Timiryazev (SBMT).

- Video materials. This section contains video documents from the RSADFP and SBMT funds.

- Collection 360. This section presents digitized museum objects from the funds of the SBMT. These objects represent high-quality digital 3D models of the fruits created by I.V. Michurin. In addition, each "exhibit" is supplied with a description.

- Library. This section contains publications on the subject of the exhibition that are included in the DL SHR content.

- Reviews. This section is created for feedback from visitors to the virtual exhibition. Here you can (after the obligatory registration) exchange opinions, make various reports on the subject of the exhibition.

- Contacts. This section contains the contacts of the administrator of the virtual exhibition for communication with him.

\section{Virtual exhibition as an example of an educational resource for universities}

A virtual exhibition "Portraits on skeletons" was created on the technological platform of the DL SHR [13]. This exhibition is dedicated to M.M. Gerasimov and his anthropological reconstructions (http://acadlib.ru/). This project was created jointly with SBMT, RSADFP and the State Darwin Museum. As part of the work on the project, more than 50 anthropological reconstructions by M.M. Gerasimov (Figure 6).

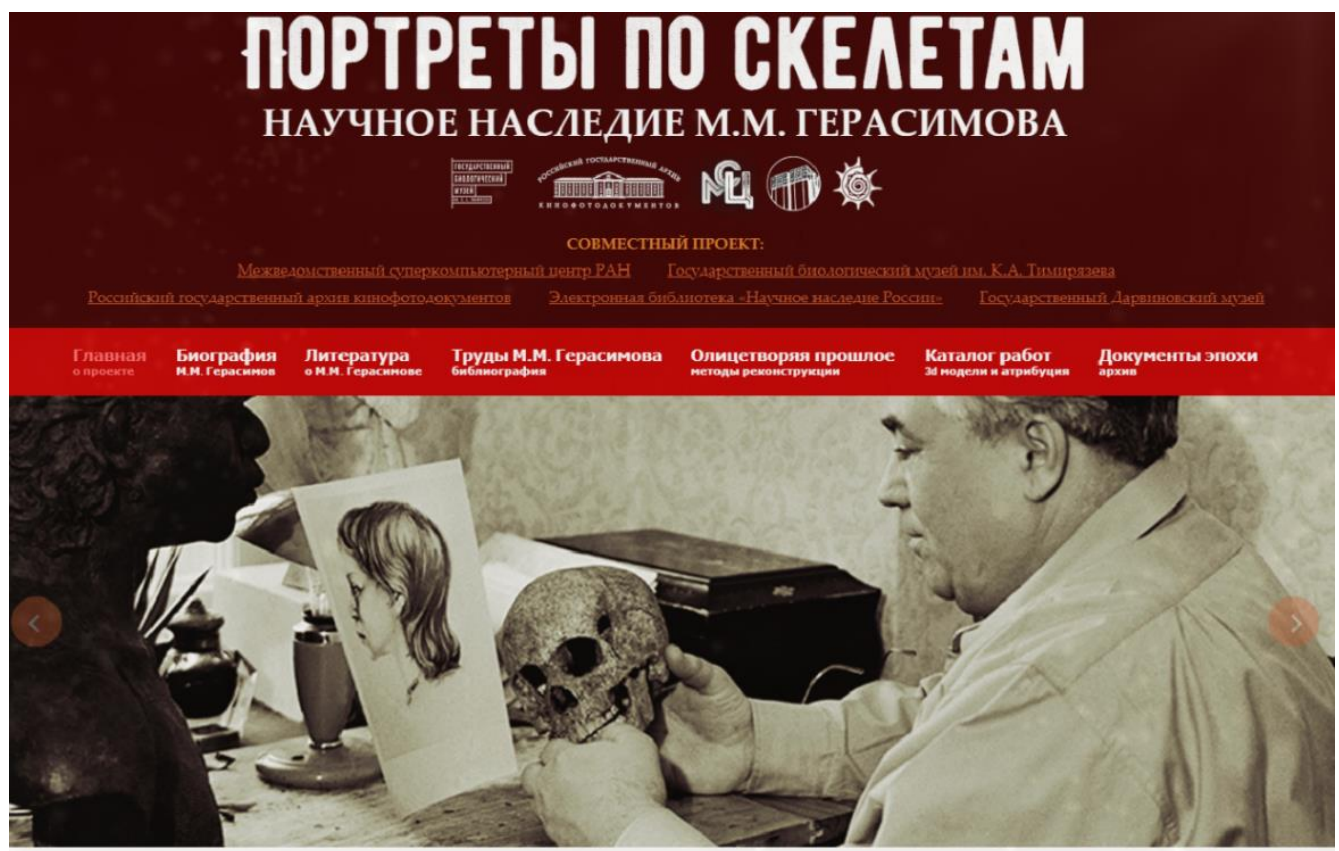

Figure 6: The main page of the "Portraits on skeletons" virtual exhibition 
This exhibition design concept is the same as that of the Garden of Life exhibition. This exhibition also contains:

- main thematic section;

- biographical section;

- section of video materials;

- section of photographic documents;

- library;

- section "Collection of 3D objects";

- reviews section;

- contacts.

However, in contrast to the exhibition "Garden of Life", the information presented at the exhibition "Portraits on skeletons" and the way it is presented is, to a greater extent, focused on university students.

\section{Conclusion}

Using the technology of creating natural science virtual exhibitions, it is possible to solve the problem of providing and popularizing scientific information to schoolchildren and students.

The proposed methods for providing scientific information can be further expanded to create other types of tools for the Single Digital Space of Scientific Knowledge formation.

The Joint SuperComputer Center of the Russian Academy of Sciences - Branch of Federal State Institution "Scientific Research Institute for System Analysis of the Russian Academy of Sciences" could act as a structure that could take over the management of the project on the formation of the CDSSK.

The research is carried out by Joint SuperComputer Center of the Russian Academy of Sciences Branch of Federal State Institution "Scientific Research Institute for System Analysis of the Russian Academy of Sciences" within the framework of a state assignment 0580-2022-0014.

\section{References}

[1] A. B. Antopol'skij and others. O edinom cifrovom prostranstve nauchnyh znanij. Vestnik Rossijskoj akademii nauk 89 (7) (2019) 728-735.

[2] A. B. Antopol'skij and others. Principy postroeniya i struktura edinogo cifrovogo prostranstva nauchnyh znanij (ECPNZ). Nauchno-tekhnicheskaya informaciya, Ser. 1 (4) (2020) 9-17. https://doi.org/10.36535/0548-0019-2020-04-2.

[3] G. I. Savin, Edinoe cifrovoe prostranstvo nauchnyh znanij: celi i zadachi. Informacionnye resursy Rossii (5) (2020) 3-5. https://doi.org/10.51218/0204-3653-2020-5-3-5.

[4] N. E. Kalenov, A. N. Sotnikov, Arhitektura edinogo cifrovogo prostranstva nauchnyh znanij. Informacionnye resursy Rossii (5) (2020) 5-8. https://doi.org/10.51218/0204-3653-2020-5-5-8.

[5] O. Ataeva, V. Serebryakov, E. Sinelnikova, Thesaurus and ontology building for semantic library based on mathematical encyclopedia. CEUR Proceedings of the Selected Papers of the 21st International Conference on Data Analytics and Management in Data Intensive Domains. 2019. pp. $148-157$.

[6] O. Ataeva, V. Serebryakov, N. Tuchkova, Mathematical physics problems: thesaurus and ontology. CEUR Proceedings of the 21st International Conference on Data Analytics and Management in Data Intensive Domains. 2019, pp. 158-168.

[7] E. V. Tkhachenko, N. N. Manko, V. E. Shteinberg, Information age trends: logical-semantic modelling data visualisation in the educational space. International Conference Education Environment for the Information Age. 2017. Vol. 28, pp. 563-576. https://doi.org/10.15405/epsbs.2017.08.66

[8] K. Pogorelko, A New Version of the Software for the Information System "Scientific Heritage of Russia”. CEUR Workshop Proceedings (CEUR-WS.org), 2021, Vol. 2990, pp. 110-116. https://doi.org/10.51218/1613-0073-2990-110-116.

[9] Y. Zagorulko, O. Borovikova, Providing the Sharing of Heterogeneous Ontology Design Patterns in the Development of the Ontologies of Scientific Subject Domains. Perspectives of system informatics. 2019. Vol. 11964, pp. 95-105. https://doi.org/10.1007/978-3-030-37487-7_8. 
[10] S. Munster, Digital Heritage as a Scholarly Field-Topics, Researchers, and Perspectives from a Bibliometric Point of View. ACM Journal on Computing and Cultural Heritage 12(3) (2019) 127. https://doi.org/ 10.1145/331001.

[11] U. Wuttke, C. Spiecker, H. Neuroth, PARTHENOS - A Digital Research Infrastructure for eHumanities and eHeritage. Bibliothek forschung und praxis 43(1) (2019) 11-20.

[12] J. Hocker, C. Schindler, M. Rittberger, Participatory design for ontologies: A case study of an open science ontology for qualitative coding schemas. ASLIB Journal of Information Management. 72 (4) (2020) 671-685. https://doi.org/10.1108/AJIM-11-2019-0320.

[13] N. Kalenov, I. Sobolevskaya, A. Sotnikov, The role of the common digital space of scientific knowledge in the educational technology development: 15th International Multi-Conference on Society, Cybernetics and Informatics, IMSCI 2021. International Institute of Informatics and Systemics, IIIS Proceedings, 2021, pp. 35-38. 